\title{
FOREIGN LANGUAGE TEACHING IN POLISH PRIMARY SCHOOLS: CONTENT-METHODOLOGICAL FOUNDATIONS
}

\section{Nataliia Kokhanova}

\section{INTRODUCTION}

Foreign language teaching in schools is one of the priority tasks implemented within the framework of the activities connected with reforms of the educational system. In the era of Poland's integration with the EU it is essential that the young generation may fully benefit from the cultural and scientific heritage of Europe as well as may bring to Europe everything that is valuable in Polish science, culture and history.

Schools have been assigned with a new, very important task related to the introduction of teaching of Western European languages on a large scale. In particular, schools are to support the development of attitudes - curiosity, openness and tolerance towards other cultures combined with increasing awareness of one's identity. The school is responsible, through foreign language teaching, for making pupils able to communicate in a foreign language. A foreign language is taught in Polish schools as a compulsory subject. English is the most popular language in grades I-III ${ }^{1}$.

Poland is entering a period when important steps will be taken to further improve the quality and accessibility of language teaching. This is a unique opportunity for a national discussion on innovative approaches and activities that will have significant consequences for future generations. Poland's accession to the European Union has given a great impetus to deeper implementation of language education in schools. The country joined the European Cultural Convention (1954), which aimed at developing mutual understanding between the peoples of Europe and protecting European culture, languages and history.

Poland has undergone two big educational reforms for the last 20 years. The socio-economic changes caused by joining Poland the European Union necessitated the reform of Polish education. The Center for Educational Research and Innovation (CERI) invited the Polish Ministry of Education to develop national standards for education and to change the criteria for

${ }^{1}$ Language education in Poland National and regional language, foreign languages and languages of national and ethnic minorities. Ministry of National Education, Poland, 2005. Paweł Poszytek, ss.10-18. Retrieved from: https://rm.coe.int/language-education-policy-profilepoland-country-report/16807b3b4a. 
determining pupils' competence, individual characteristics of students and their potential.

Consequently, implementation of foreign languages into the learning process from the first form is a follow-up to the European trend and is a valuable complement to national policies and development of national linguistic potential. The educational system and teaching in Poland are based on universal principles of ethics. Education is aimed at developing a sense of responsibility of young people, a love for Motherland and respect for cultural heritage, and discovery of the cultural values of Europe and the world. The school should provide each student with conditions necessary for his development, to prepare the student for fulfilling family and community responsibilities based on the principles of solidarity, democracy and tolerance ${ }^{2}$.

Education in Poland is a common law of the whole society. It is guided by the principles contained in the Constitution of the Republic of Poland, as well as the guidelines contained in the Universal Declaration of Human Rights, the International Covenant on Civil and Political Rights and the Convention on the Rights of the Child. In particular, Article 70 of the Constitution of Poland (Konstytucja Rzeczypospolitej Polskiejz dnia 2 kwietnia 1997) provides that everyone is entitled to compulsory education and training up to the age of $18^{3}$.

Education is compulsory for all children from 7 years. Primary school starts at the age of 7 and ends at 13. Primary education is divided into two parts (stages):

- grades 1-3 - where pupils learn more general material and there is no split for individual subjects;

- grades 4-8 - where pupils have a subject related classes such as Polish language, Math, Geography, Science etc.

Particular attention is paid to teaching English in primary school, because the tendency to learn languages is much greater in the childhood. During primary school education students have to master key competencies that involve their personal, social and intellectual development. Knowledge is formed on an interdisciplinary basis and is an integrated result of subject and intersubject competencies. Studying English at an early stage helps to receive basic knowledge and develop a sense of language of junior pupils.

${ }^{2}$ Vasyliuk, A., Liashenko, L. (2002). Novi pidkhody do planuvannia i reformuvannia osvity (zarubizhnyi dosvid) [New Approaches to Planning and Reforming Education (Foreign Experience)]. Osvita i upravlinnia, T. 5, № 1 (in Ukrainian).

${ }^{3}$ Konstytucja Rzeczypospolitej Polskiejz dnia 2 kwietnia 1997 r. 


\section{Content of foreign language education in the primary school of Poland}

Primary school is an important element of learning and foundation for further successful acquisition of the necessary knowledge and skills. During the study in primary school, students should acquire key competences that anticipate their personal, social and intellectual development, that are formed on a cross-curricular basis and are an integrated result of subject and crosscurricular competences. An important role in teaching English in primary school is given to the school curriculum, its relevance to the National Curriculum and the choice of textbooks that will meet the requirements of both curricula.

Primary school in Poland lasts eight years. The first three grades (7-9 years) offer a basic course of education, and the remaining grades (10-15 years), equivalent in lower secondary school in some western countries, introduce "secondary" studies. Graduates of primary school can continue studies in upper secondary or vocational schools ${ }^{4}$.

Following the political breakthrough of 1989, Poland witnessed an education reform that resulted in the new National Core Curriculum for Preprimary Education (1999). The reform has set in motion subsequent amendments to the National Core Curriculum, which reflects the tendencies inherent in Polish education policies to centralize the education system.

In this work we determine content of the National and School Curricula used for teaching English in state primary schools in Poland and to define the role of the textbooks in the educational process.

The term curriculum refers to the lessons and academic content taught in a school or in a specific course or program. In dictionaries, curriculum is often defined as the courses offered by a school, but it is rarely used in such a general sense in schools. Depending on how broadly educators define or employ the term, curriculum typically refers to the knowledge and skills students are expected to learn, which includes the learning standards or learning objectives they are expected to meet; the units and lessons that teachers teach; the assignments and projects given to students; the books, materials, videos, presentations, and readings used in a course; and the tests, assessments, and other methods used to evaluate student learning. An individual teacher's curriculum, for example, would be the specific learning standards, lessons, assignments, and materials used to organize and teach a particular course. Since curriculum is one of the foundational elements of

4 Siemak-Tylikowska, A. (1993). Curriculum development in secondary education in Poland. Journal of Curriculum Studies, vol. 25, Issue 1. Retrieved from: https://www.tandfonline.com/doi/abs/10.1080/0022027930250106?src=recsys. 
effective schooling and teaching, it is often the object of reforms, most of which are broadly intended to either mandate or encourage greater curricular standardization and consistency across states, schools, grade levels, subject areas, and courses ${ }^{5}$.

All schools develop the curriculum to make sure every child receives a balanced, consistent education.

The curriculum sets out:

- areas of learning to be taught;

- cross-curricular and other skills every pupil should develop;

- levels of knowledge, understanding and skills to be developed in each area;

- levels of progression - teachers will use these to assess the child's progress in developing skills of communication, using mathematics and ICT;

- how the child's progress is assessed and reported.

The educational process in the primary school of Poland is regulated by the National Curriculum and the School Curriculum.

The National Curriculum (first introduced in 2009) formed the basis of instruction in all schools. Starting from September a new core curriculum is being introduced on the Regulation by the Ministry of National Education of 23 December 2008 on Core curricula for preschool and general education in particular types of schools. The new core curriculum, which focuses on learning outcomes and acquisition of key competences, was expected to be fully implemented (i.e. up to grade 6) by 2014/2015. According to the new core curriculum, pupils enrolled in primary school are expected to: acquire a basic set of information/knowledge on facts, theories and practice related in particular to topics and phenomena close to their experience; acquire skills related to the use of knowledge and information in carrying out tasks and solving problems; develop attitudes related to efficient and responsible functioning in the contemporary world. Core curricula have to be implemented by all schools, but teachers are free to follow one of the selected curricula from the list approved by the Ministry or prepared by the teacher or a team of teachers as well as to use diverse textbooks selected from a list approved by the Ministry ${ }^{6}$.

The National Curriculum divided education into four 3-year periods, and for each period it specified teaching objectives and expected learning outcomes for each subject. All teachers were obliged to incorporate the

5 The glossary of education reform. Retrieved from: https://www.edglossary.org/ curriculum/.

6 World Data on Education, Poland, $7^{\text {th }}$ edition 2010/2011. Retrieved from: http://www.ibe.unesco.org/sites/default/files/Poland.pdf. 
National Curriculum into their own grade-specific syllabus or to choose a commercial syllabus.

On January 30, 2018, the Ministry of National Education of Poland signed a new regulation on the National Curriculum of Primary Education for a 3-year general primary school. The new National Curriculum for Primary Schools has been launched since the 2018/2019 school year (the first grade).

Primary education in Poland is determined by three elements: National Curriculum, School Curriculum and timetable. The national curriculum defines the content of the school curriculum in primary education. It includes a list of teaching and learning goals, as well as the amount of knowledge, skills and competencies that students need to acquire at primary level. The school curriculum is developed by teachers, taking into account the age and abilities of the students. Timetable defines the weekly number of hours that are required for compulsory general education classes for elementary and high school students.

A new National Curriculum, which was set out in the Regulation of the Minister of National Education in the $14^{\text {th }}$ of February in 2017 for pre-school education and general education in primary school, was implemented in the Polish school system with an eight-year primary school. Thus, primary school education in Poland is based on the National Curriculum, which defines learning outcomes and general requirements for the organization of primary education. Concerning English language learning, the National Curriculum focuses on developing key competences and improving the effectiveness of modern foreign language learning, giving students the opportunity to study foreign languages systematically and to bilingual education.

The National Curriculum (first introduced in 2009) is a required base for school curricula in all schools. It divides education into three periods, and it defines goals and expected learning outcomes for all subjects for each period. Each school must adhere to the National Curriculum completing the school curriculum. All teachers are required to complete the school curriculum in accordance with the National Curriculum. The national curriculum is implemented through the school curriculum, which defines what the goals and content of education are in primary school. Teachers are free to use the curriculum developed by them or to choose another curriculum, that is approved by the head of the school after consultation with the Board of Teachers. The school curriculum can be developed or changed by the teacher or in collaboration with other teachers or selected by a teacher from a set of curricula prepared by other authors. The curriculum offered by the teacher must be based on the National Curriculum and take into account the needs and abilities of the students. Teachers may also use textbooks 
chosen from a list approved by the Ministry of National Education of Poland.

According to the National Curriculum, in primary grades (1-3) integrated learning is provided by a general teacher. Music education, art education, physical education, computer lessons and modern foreign language lessons should be conducted by a teacher with appropriate qualifications.

Polish primary education of the first stage is aimed at supporting children in their intellectual, emotional, social, ethical, physical and aesthetic development. The new National Curriculum defines the amount of knowledge and skills that students which are going to graduate the third form should acquire. The amount of knowledge and skills that students need to acquire after graduating from grade 3 is determined by children of intermediate ability ${ }^{7}$.

The National Curriculum provides division into groups during compulsory foreign language lessons if there are more than 24 students in forms. Students should be grouped according to their language skills. In addition, lessons can be taught in interclasses or cross-groups with no more than 24 students.

According to the National curriculum at the first stage of education each student is required to learn one modern foreign language, while from class VII at the second stage of education - two modern foreign languages. So, the National curriculum for primary school have such goals concerning teaching English:

- the target level after completing the first educational stage A1;

- shaping a positive attitude to learning a foreign language at further stages of education;

- comprehensive development of the child, his passion and interests;

- developing skills of cooperation with peers;

- building awareness of other languages and cultures and shaping attitudes of curiosity about tolerance towards them;

- foreign language should eventually become a communication tool during classes;

- ability to use basic language resources concerning the student and his environment.

The first stage student uses a basic language resource about himself and his immediate surroundings on the following topics:

1) me and my relatives (family, friends);

7 The system of education in Poland (2014). Foundation for the Development of the Education System, Warsaw. Retrieved from: http://www.fss.org.pl/sites/fss.org.pl/files/the system_2014_www_0.pdf, p. 34 . 
2) my place of living (my home, place);

3) my school;

4) popular professions;

5) my day, my games;

6) food;

7) shops and shopping;

8) my free time and holidays;

9) holidays and traditions of my country;

10) sports;

11) my well-being;

12) nature around me;

13) the world of fairy tales and fantasy ${ }^{8}$.

In addition to these outlined topics, students should understand simple verbal and written statements and stories, respond to commands, write very simple and short sentences, and speak on a sample and independently. As for oral language, students should repeat and reproduce words and simple sentences, make simple and short statements in accordance with the template. Students also need to know that there are different languages and people in different countries can speak different languages, and that it is worth learning their language to be able to communicate with them. Students should use sources of information in the modern foreign language (dictionaries and books), as well as use information and communication technologies using a foreign language?

We conducted a general analysis of the English language learning process in Polish primary schools and the school curriculum they use when teaching a language. Many schools use Kid's Box textbooks by Cambridge University Press. For planning English lessons, teachers use English language curriculum by Cambridge University Press (Cambridge Primary Curriculum). The Cambridge Curriculum combines world-class curriculum with quality support of teachers and integrated assessment.

The Cambridge Curriculum offers an additional testing framework for student assessment and a system of progress reports for students and parents. These assessments provide international benchmarks that allow teachers to identify students' strengths and weaknesses and develop further learning using test results.

\footnotetext{
${ }^{8}$ Studzińska, I., Mędela, A., Kondro, M., Piotrowska, E., Sikorska, A. (2017). Program nauczania języka angielskiego dla klas 1-3 szkoty podstawowej Macmillan Polska.

${ }^{9}$ Podstawa programowa ksztatcenia ogólnego dla szkoły podstawowej (2017). Retrieved from: https://legislacja.rcl.gov.pl/docs//501/12293659/12403198/dokument274507.pdf.
} 
For primary English language, the Cambridge Curriculum is presented in five substantive areas, which are further subdivided into groups. These are five areas and their groups:

1. Phonetics, spelling and vocabulary.

2. Grammar and punctuation.

- Reading;

- Writing.

3. Reading.

- Fiction and poetry;

- Non-Fiction.

4. Writing.

- Fiction;

- Non-Fiction;

- Presentations.

5. Speaking and listening.

The school curriculum aims at enabling students to communicate confidently and effectively and developing critical skills in order to respond to the information they receive and read texts with pleasure and understanding. Cambridge Curriculum provides a solid foundation upon which further stages of education can be built ${ }^{10}$.

We found out that textbooks by Pearson publishing are also popular in Polish primary schools. English Language Program for 1-3 grades by Mariola Bogucka can be a base for the textbook of this publishing house. M. Bogucka's program is based on the idea that the student is at the center of the learning process, and the role of the teacher is to choose the methods of teaching, taking into account the child's development, his needs and interests. According to this curriculum the content of learning of the first stage should correspond to the level of cognitive development and emotional state of the pupils. Development of children of 7-9 years old is special, which is why foreign language teachers decide for themselves how to raise the level of complexity of learning English and how to devote to repeating and consolidating new material.

At the initial stage of learning a foreign language, the main goal is to get the pupil interested in learning. At the first and second grades, students provide mostly oral answers to the teacher's questions. In the first stage of

${ }^{10}$ Cambridge Primary English Curriculum outline for 2015, 2016 and 2017. Retrieved from: https://www.cambridgeinternational.org/Images/23894-cambridge-primary-englishcurriculum-outline.pdf. 
teaching, the teacher begins to introduce the elements of reading. English is mostly about games, often using visuals, word cards and pictures ${ }^{11}$.

A lot of teachers work with the help of the Bugs World and Hot Spot textbooks by Macmillan publishing. As a basis for the school curriculum, the teachers of schools, where these textbooks are used, have chosen the English language teaching program at the first stage of teaching by Ilona Studzinska, Arkadius Medeli, Magdalena Kondro, Eva Petrovskaya, Anna Sikorska. It has been found out that the goals of this program are fully in line with the learning objectives outlined in the National Curriculum. The program determines development of all language skills, especially in the early stages of language learning, the focus is on development of speaking and listening skills. In addition, this program provides that when learning English in grades 1-3 in primary school, students will be able to reproduce different language skills in English in relevant situational and thematic contexts. At the end of the 3 grade, students should be able to master vocabulary, ask and answer questions, make descriptions and engage in dialogues within the topics studied ${ }^{12}$.

We have tracked how the school curriculum fits with the chosen textbooks (table 1).

Table 1

\begin{tabular}{|l|l|}
\hline \multicolumn{1}{|c|}{ Textbooks } & \multicolumn{1}{c|}{ Curriculum } \\
\hline $\begin{array}{l}\text { Kid's Box by Cambridge } \\
\text { University Press }\end{array}$ & Cambridge Primary Curriculum \\
\hline $\begin{array}{l}\text { New English Adventure } \\
\text { by Pearson }\end{array}$ & $\begin{array}{l}\text { Program nauczania języka angielskiego dla } \\
\text { klas I-III }\end{array}$ \\
\hline $\begin{array}{l}\text { Bugs World and Hot Spot } \\
\text { by Macmillan }\end{array}$ & $\begin{array}{l}\text { Program nauczania języka angielskiego dla } \\
\text { I etapu edukacyjnego szkoła podstawowa, } \\
\text { klasy 1 - 3 Ilona Studzińska Arkadiusz } \\
\text { Mędela Magdalena Kondro Ewa Piotrowska } \\
\text { Anna Sikorska }\end{array}$ \\
\hline
\end{tabular}

11 Program nauczania języka angielskiego dla klas I-III. Retrieved from: https://www.pearson.pl/fileadmin/poland/english/products/files/Programy_nauczania/klasy_1_8 _nowa_podstawa_2017/Program_nauczania_jezyka_angielskiego_dla_klas_1-

3_zgodny_z_podstawa_programowa_z_14_lutego_2017.pdf.

${ }_{12}$ Program nauczania języka angielskiego dla I etapu edukacyjnego szkoła podstawowa, klasy 1 - 3 Ilona Studzińska Arkadiusz Mędela Magdalena Kondro Ewa Piotrowska Anna Sikorska MACMILLAN POLSKA 2017. Retrieved from: https://www.macmillan.pl/downloads/ PROGRAM_NAUCZANIA_I-III_2017.pdf. 


\section{Textbook as a means of formation of the English-speaking competence of junior schoolchildren}

Mental and personal development of a child of the primary school age is determined by peculiarity of the social situation of development - education in primary school. At this age, learning is based on cognitive interest and a new social position, and it becomes a leading activity.

Learning tools are an important part component of the educational process of foreign languages. The definition of means of learning is the answer to the question "What do we have to teach with?". Therefore, a variety of material things can be provided by the teaching aids to help the teacher organize effective teaching of a foreign language, and to pupils to master it successfully. In the methodology of teaching foreign languages there are certain requirements to learning tools, in particular:

a) to be in material form and perform its main function, namely, to be such a means of work that provides realization of joint activity of a teacher and a pupil in the process of learning a foreign language;

b) to be goal-oriented, that is, promote the goals;

c) to be tools for implementing the methods and techniques used in the learning process, and to manage activities of a teacher and a pupil;

d) to correspond to the modern achievements of the methodology of teaching foreign languages and to ensure implementation of the latest technologies of learning a foreign language ${ }^{13}$.

In view of this and taking into account the specifics of the child's development at this age, there is a need for a communicative method of teaching English. Junior pupils need interesting and meaningful lessons for better learning and further productive work. One of the main tools in primary school is a textbook. It must meet all the requirements for the content of education, be interesting, concise and accessible, at the same time stable and varied, it must ensure that students fully master the educational material.

A textbook is a book that sets out the basics of scientific knowledge in a particular subject in strict accordance with learning objectives established by the program of the subject and the requirements of didactics. The textbook has several important functions:

- motivational - substantiation of significance of the material being studied, original illustrations, etc.;

${ }^{13}$ Hryshkova, R. O. Suchasnyi pidruchnyk inozemnoi movy yak zasib mizhkulturnoho spilkuvannia [Modern textbook of Foreign language as a means of intercultural communication]. Naukovi pratsi, Vyp. 15. Pedahohichni nauky, 165-169 (in Ukrainian). 
- information - providing necessary information within the framework of the subject;

- transformational - transformation of the material of science in accordance with age characteristics of pupils;

- systematizing - systematic and consistent presentation of material in the logic of the subject;

- securing and exercising self-control by pupils - providing opportunities for re-studying texts, verifying correctness of the learned material;

- coordinating - attracting other means of training;

- educational - development of the skills of self-education, taking notes, generalizing, highlighting the main thing, etc.;

- developing and educational - focus on the formation of certain moralvalue attitudes.

Many scholars indicate that textbooks seem to be the main teaching resources in EFL classrooms. Patricia Byrd claims most teachers depend on textbooks - often as a required tool - because they provide content and activities that shape what happens in the classroom. González says textbooks became an alternative for three main reasons: they are apparently eclectic alternatives to save time and money, they include pictures and graphic materials that may be more efficient than the teacher's descriptions, and they contain all kinds of objects that may be difficult to bring into the classroom. EFL textbooks are, indeed, a major necessity for most teachers, because the bulk of them feature an eclectic approach based on the current theories proposed by communicative trends. For instance, Task-based approach engages learners in problem-solving tasks. Content-based approach also offers opportunities to deal with interesting topics and subject matter, rather than coping with grammar-oriented lessons. Moreover, collaborative learning encourages students to work in groups, as an ideal way to exchange information socially and meaningfully. According to Richards and Rodgers, textbooks are designed in such a way that their tables of contents suggest a gradual development of language forms and functions, going from the most basic to the most complex. All these approaches and features are intended to develop the use of communicative language. However, despite considerable effort on the part of text designers, editors, and publishing houses, a range of grammar-oriented activities and mechanical practice continues to prevail. As a first step, it is crucial to differentiate three main types of language practice found in most English instructional materials, according to Richards:

1. Mechanical practice refers to controlled activities that involve repetition and substitution drills. They are designed to practice the use of particular grammar items. In many textbooks, this practice demands 
sentence completion (usually with grammar activities in isolation) but lacks authentic language negotiation.

2. Meaningful practice refers to activities in which language is still controlled and "students are required to make meaningful choices when carrying out practice".

3. Communicative practice embodies those activities in which language "is not totally predictable". Language production at this level is more spontaneous and authentic, because meaning negotiation takes place "within a real communicative context" and "real information is exchanged"14.

Therefore, if textbooks are designed to develop language competence, one can assume they should contain a well-balanced number of activities pertaining to all the types of language practice.

As a learning tool, a textbook holds a special place in the set for the pupil, it is main. It contains methodologically organized linguistic and speech material, exercises for mastering this material in various types of speech activity (except for the texts for listening, which are in the teacher's book), grammar material, an appendix (songs, poems, vocabulary, etc.).

The structure of the textbook depends on the methodological concept of the authors. Traditionally, textbooks are organized according to thematic or situational-thematic principles into sections that are relatively complete sections of the content of teaching of four types of speech activity: speaking, listening, reading and writing. Each section usually covers a group of lessons and has a lesson structure. A variety of visual aids can be used in the textbook: pictures, diagrams, tables, figures, symbols, different fonts, color and more.

Therefore, the textbook should contain all of that is necessary to achieve the learning aims. Among the basic requirements for the structure and content of the textbook are the following:

a) a textbook should ensure that new language material is consistently delivered from lesson to lesson;

b) content of the textbook should be communicative;

c) each paragraph of the textbook should have a "core" around which all the material is organized (such a "core", for example, may be a typical phrase, topic, etc.);

d) there should be a special section in the structure of the paragraph homework;

${ }^{14}$ Gómez-Rodríguez, L. F. (2010). English Textbooks for Teaching and Learning English as a Foreign Language: Do They Really Help to Develop Communicative Competence? Educ.Educ., vol. 13, no. 3. Retrieved from: http://www.scielo.org.co/scielo.php?script=sci_ arttext\&pid=S0123-12942010000300002. 
e) the structure and content of the textbook should ensure that both oral and written communication skills are mastered in parallel.

The textbook, as a means of teaching language, as well as formation of linguistic and socio-cultural competence, models the language learning system adopted by the authors. This system includes learning, content of the subject, features of the process of formation of knowledge, skills and abilities, methods and means of training. The main tools used in the textbook to realize the goals and objectives of learning a foreign language are exercises and tasks. The content of the textbook should contain a variety of situations that simulate communication.

The construction of the content of the textbook should be based on certain patterns, namely:

- the purpose of teaching foreign language at the initial stage determines content of the relevant textbooks and is a component of the overall purpose of teaching this subject in an education institution;

- successful realization of the goal and effective use of the content depend on the chosen means of training: linguistic, speech and thematic informational educational material, exercises and tasks, extra-textual materials;

- age-specific psychological characteristics of primary school pupils, their interests, communication needs and educational experience serve as a basis for determining the types and forms of educational activity;

- the level of motivation of the educational activities to be performed by the junior pupils is a prerequisite for the conscious and successful mastery of the content of the textbooks;

- effectiveness of the learning process depends on the didactic and methodological appropriateness of the methods, techniques and forms of presentation and activation of the training material offered by the textbooks, as well as on the methods and forms of controlling the level of its assimilation;

- the content of the textbooks should provide students with opportunities to demonstrate their own language skills in different types of speaking activities, to observe dynamics of their development and to reflect on the results of their work, to see a tendency for their improvement and, if necessary, to adjust the acquired experience in accordance with their own communicative intentions;

- the content of the textbooks should not strictly regulate the work of the teacher, but, on the contrary, enable him to effectively guide the activities of students, sometimes having the opportunity to vary the content offered, which is conditioned by learning needs, in particular learning conditions; 
- one of the priority principles for development of modern foreign language school education is interconnected learning by pupil of foreign language communication and the culture of the people whose language is being learned, which should be clearly reflected in the content of the educational literature ${ }^{15}$.

We have relied on these rules to analyze the content of English school textbooks for students in grades 1-3 which are used in Polish primary schools. We have found out that most Polish primary schools use in teaching process the textbooks which were published by Pearson, Express Publishing, Oxford University Press, Macmillan Education. Our analysis was generalized. These are results:

1. The content of the textbooks has been developed in accordance with the National Curriculum and in accordance with the requirements of the existing foreign language curricula.

2. The content of the textbooks for each class presents all spheres and topics of communication, language and speech material, as well as information of the socio-cultural sphere, outlined in the content of the curriculum.

3. Methods and forms of activity offered by textbooks for presentation, activation and control of the level of educational material mastering, aimed at mastering foreign language communication by pupils in oral and written forms.

4. The content of the textbooks corresponds to age characteristics of pupils, their interests, needs and educational experience.

5. In general, the content of the textbooks ensures a balanced mastery of linguistic and speech material, including foreign language communication in four types of speech activity (speaking, listening, reading, writing).

6. Textbooks are characterized by integrity and systematic presentation of educational material.

7. The textual material of the majority of textbooks corresponds to the samples of authentic language adopted in the country of the language being taught.

8. Textbook materials facilitate communication (practical), educational, educational and educational goals of learning.

9. The textbooks show the continuity of content development between years of study.

${ }^{15}$ Redko, V. H. (2015). Yaka navchalna literatura z inozemnoi movy potribna suchasnomu uchniu: rezultaty analizu zmistu pidruchnykiv dlia pochatkovoi shkoly [What foreign language literature does a modern student need: results of content analysis for elementary school textbooks]) (in Ukrainian). 
10. The content of the textbooks focuses on the European Guidelines for Language Education and is mainly capable of achieving the intended level of learning by pupils of primary school - A1.

\section{CONCLUSIONS}

Consequently, as a result of our study of the issue outlined above, we have come to the conclusion that public primary schools in Poland are subordinated to teaching of the National Curriculum, which was approved on February 14, 2017. Primary school teachers choose pre-made school curricula from well-known publishers such as Cambridge University Press, Pearson, Macmillan, and these curricula are in line with the National Curriculum and are not significantly different. Also, primary school teachers independently select textbooks according to the school curriculum publisher and schedule, according to the distribution of hours and division into English language teaching groups at each education institution.

An important place in educational process belongs to the school textbook as the main means of teaching language. This is conditioned by active reorientation of the foreign language education paradigm to a competent, communicative, activity-oriented and culturally-oriented direction of the educational process. In this regard, the model of a modern school textbook in a foreign language can be considered as based on defining its twofold essence: 1) as a carrier of the content of a foreign language education and 2 ) as a means of teaching foreign language communication. Therefore, the textbook should be a didactic tool that effectively and rationally integrates the students' teaching activities and the teacher's methodological work, that is, in it the substantive and procedural aspects are interconnected.

\section{SUMMARY}

The article deals with the content of the National curriculum in Poland, which regulates English teaching in Polish primary schools. It has been noted that an important role in English teaching in primary school is given to the school curriculum, its correspondence with the National curriculum and the choice of textbooks that must meet the requirements of both curricula. The New National curriculum defines the amount of knowledge and skills that graduates from the 3 rd year course must receive. It has been found out that Polish primary school teachers use the curriculum offered by leading English language textbook publishers such as Cambridge University Press, Pearson, Macmillan as a school curriculum. It has been proved that the school curriculum aims to enable students to communicate confidently and effectively and develop language skills. A modern analysis of the National curriculum and school curricula has shown that the expedient choice of textbooks and teaching methods supports positive learning motivation, 
develops pupils' search interest and motivates using acquired knowledge in everyday life.

\section{REFERENCES}

1. Language education in Poland National and regional language, foreign languages and languages of national and ethnic minorities. Ministry of National Education, Poland, 2005. Paweł Poszytek, ss.10-18. Retrieved from: https://rm.coe.int/language-education-policy-profile-poland-countryreport/16807b3b4a.

2. Vasyliuk, A., Liashenko, L. (2002). Novi pidkhody do planuvannia i reformuvannia osvity (zarubizhnyi dosvid) [New Approaches to Planning and Reforming Education (Foreign Experience)]. Osvita i upravlinnia, T. 5, № 1 (in Ukrainian).

3. Konstytucja Rzeczypospolitej Polskiejz dnia 2 kwietnia 1997 r. (in Ukrainian).

4. Siemak-Tylikowska, A. (1993). Curriculum development in secondary education in Poland. Journal of Curriculum Studies, vol. 25, Issue 1. Retrieved from: https://www.tandfonline.com/doi/abs/10.1080/ 0022027930250106 ? src $=$ recsys.

5. The glossary of education reform. Retrieved from: https://www.edglossary.org/curriculum/.

6. World Data on Education, Poland, $7^{\text {th }}$ edition 2010/2011. Retrieved from: http://www.ibe.unesco.org/sites/default/files/Poland.pdf.

7. The system of education in Poland (2014). Foundation for the Development of the Education System, Warsaw. Retrieved from: http://www.fss.org.pl/sites/fss.org.pl/files/the system_2014_www_0.pdf, p. 34 .

8. Studzińska, I., Mędela, A., Kondro, M., Piotrowska, E., Sikorska, A. (2017). Program nauczania języka angielskiego dla klas 1-3 szkoły podstawowej Macmillan Polska.

9. Podstawa programowa ksztatcenia ogólnego dla szkoły podstawowej (2017). Retrieved from: https://legislacja.rcl.gov.pl/docs//501/12293659/ 12403198/dokument274507.pdf.

10. Cambridge Primary English Curriculum outline for 2015, 2016 and 2017. Retrieved from: https://www.cambridgeinternational.org/Images/ 23894-cambridge-primary-english-curriculum-outline.pdf.

11. Program nauczania języka angielskiego dla klas I-III. Retrieved from: https://www.pearson.pl/fileadmin/poland/english/products/files/ Programy_nauczania/klasy_1_8_nowa_podstawa_2017/Program_nauczania _jezyka_angielskiego_dla_klas_1-

3_zgodny_z_podstawa_programowa_z_14_lutego_2017.pdf.

12. Program nauczania języka angielskiego dla I etapu edukacyjnego szkoła podstawowa, klasy 1 - 3 Ilona Studzińska Arkadiusz Mędela 
Magdalena Kondro Ewa Piotrowska Anna Sikorska MACMILLAN POLSKA 2017. Retrieved from: https://www.macmillan.pl/downloads/ PROGRAM_NAUCZANIA_I-III_2017.pdf.

13. Hryshkova, R. O. Suchasnyi pidruchnyk inozemnoi movy yak zasib mizhkulturnoho spilkuvannia [Modern textbook of Foreign language as a means of intercultural communication]. Naukovi pratsi, Vyp. 15. Pedahohichni nauky, 165-169 (in Ukrainian).

14. Gómez-Rodríguez, L. F. (2010). English Textbooks for Teaching and Learning English as a Foreign Language: Do They Really Help to Develop Communicative Competence? Educ.Educ., vol. 13, no. 3. Retrieved from: http://www.scielo.org.co/scielo.php?script=sci_arttext\&pid=S012312942010000300002.

15. Redko, V. H. (2015). Yaka navchalna literatura z inozemnoi movy potribna suchasnomu uchniu: rezultaty analizu zmistu pidruchnykiv dlia pochatkovoi shkoly [What foreign language literature does a modern student need: results of content analysis for elementary school textbooks] (in Ukrainian).

Information about the author: Nataliia Kokhanova,

Post graduate student, Sumy State Pedagogical University named after A. S. Makarenko

87, Romenska str., 40002, Sumy, Ukraine ORCID ID: orcid.org/0000-0002-7458-9087 